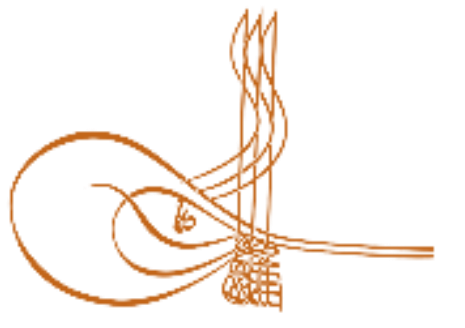

www.turkishstudies.net/turkishstudies
Turkish Studies

eISSN: $1308-2140$

Research Article / Araştırma Makalesi

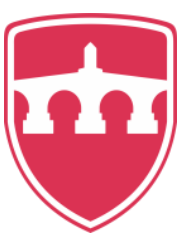

INTERNATIONAL

BALKAN

UNIVERSITY

Sponsored by IBU

\title{
Üniversite Öğrencilerinin Genel Erteleme Davranışları ile Akademik Erteleme Davranışları Arasındaki İlişki
}

\author{
The General Procrastination Behavior of University Students and The Relationship Between The \\ Academic Procrastination Behavior
}

Nuran Öztürk Başpınar*

\begin{abstract}
Introduction: Deferring behavior stands out as a behavior that delays or even prevents the individual from achieving his goals. The idea that students' general procrastination behavior may have an effect on academic procrastination behavior makes the subject worth researching. Therefore, the purpose of the study is; It was determined to reveal the general and academic procrastination behaviors of university students and the relationship between these two behaviors. "What is the relationship between General postponement behaviors of university students and academic postponement behaviors?"his question has been designated as a fundamental research question. Methods: The sample of the study consists of 1st and 2nd grade students (140 volunteers persons) from the Department of Office Management and Executive Assistantship and Department of Real Estate and Real Estate Management of Anadolu University Eskişehir Vocational School. In the research designed with quantitative research method, the data were collected from the students in the specified sections according to random sampling method. In the research, "Academic Procrastination" and "General Procrastination" scales, whose validity and reliability have been proved by Çakıcı (2003), were used. The results of the data were analyzed with the help of various scientific methods and the effect of general procrastination behavior on academic procrastination behaviors was determined. Results: The analyzes revealed that students have a tendency to postpone general and academic. According to the data obtained, there is a significant, high and positive relationship between students' academic procrastination tendencies and general procrastination tendencies. This result will show the academic procrastination behavior of the individual who shows general procrastination behavior; or vice versa, it can be interpreted that a person who shows academic procrastination behavior will also show the general procrastination behavior.
\end{abstract}

Structured Abstract: Introduction and purpose of study. The tendency to delay; It is a problem that affects individuals and organizations, which can be seen in all areas of life, affecting millions of people of all ages and professions. While the values of success and productivity are increasingly important, it is seen that the goals to be achieved are delayed. Procrastination is a condition in which a person delays the decisions they have taken or the work they have to do (Sirois, 2007). There are several reasons for procrastination: Personal predisposition, lack of decision-making skills (Milgram\&Toubiana, 1999) avoiding make decisions,

\footnotetext{
* Dr. Öğr. Üyesi, Anadolu Üniversitesi, Eskişehir Meslek Yüksekokulu, Büro Hizmetleri ve Sekreterlik Bölümü Asst. Prof. Dr., Anadolu University, Eskişehir Vocational School, Department of Office Services and Secretariat ORCID 0000-0002-0913-4350

nbozturk@anadolu.edu.tr

Cite as/ Atıf: Öztürk Başpınar, N. (2020). Üniversite öğrencilerinin genel erteleme davranışları ile akademik erteleme davranışları arasındaki ilişki, Turkish Studies, 15(2), 1197-1219. https://dx.doi.org/10.29228/TurkishStudies.41436

Received/Geliş: 21 January/Ocak 2020

Accepted/Kabul: 25 April/Nisan 2020

Checked by plagiarism software

Copyright $(\mathrm{C}$ MDE, Turkey 
unwillingness to take responsibility or like spending time on social media and avoiding work (Özdemir, 2012; Topal, 2015; Uzun\&Demir, 2015). Deferring behavior stands out as a behavior that has a small/large and internal/external cost and delays or even prevents the individual from achieving his goals.

In this study; the idea that students' general procrastination behaviors may have an effect on academic procrastination behaviors has made the subject worth researching. Therefore, the purpose of the study is; it was determined to reveal the general and academic procrastination behaviors of university students and the relationship between these two behaviors. "What is the relationship between the general procrastination behaviors of university students and academic procrastination behaviors?" Was determined as the basic research question and the following hypotheses were tested: tendencies.

H1: There is a significant relationship between students' general and academic procrastination

H2: The general procrastination levels of students differ significantly according to demographic characteristics.

H3: The academic procrastination level of students differs significantly according to demographic characteristics.

Conceptual framework. Saddler and Sacks (1993) classified the procrastination as general and academic procrastination. Academic procrastination can almost always be described as postponing academic tasks and almost always feeling anxious about it and leaving an assignment to the last day or like starting a lesson the day before the exam exemplified (Ferrari, 1991).

In previous studies, it has been determined that approximately $70 \%$ of university students display academic procrastination behavior (Ellis\&Knaus, 1977; Ferrari vd., 2005). In a similar studies conducted in Turkey, this ratio is seen to take place at a lower level between $60 \%-50 \%$ (Ozer, 2007). In a study conducted by Ferrari and Scher (2000) with university students, it was determined that the students in the scope postponed both academic tasks such as preparing homework, presentations, and duties such as home cleaning and sports.

Many studies have shown that academic procrastination is one of the most important causes of academic failure (Schouwenburg vd., 2004; Akinsola vd., 2007; Beswick vd., 1988; Wang\&Englander, 2010; Orpen, 1998; Rothblum vd., 1986). In the research conducted in academic procrastination in Turkey it was revealed that there was a significant negative correlation between academic achievement (Akkaya, 2007; Bulut, 2015; Çetin, 2009). Many studies have reported that academic procrastination often leads to academic fraud, such as plagiarism (Klassen vd., 2008; Patrzek vd., 2015, Sirois vd., 2003).

The fact that the departments that are studied are different and the homework, practices, exams or the lack or high number of projects can be effective in the emergence of academic procrastination behavior (Balk1s, 2007, akt. Çelik\&Odac1, 2015). Researches has shown that inadequacy in time management also increases the tendency to procrastination (Milgram vd., 1995; Orpen, 1998 \& De Raad, 2000). Sarikaya and Aydın-Kocak in Turkey (2016) according to their research; There is a negative, moderate and significant relationship between students' time management skills and academic procrastination behaviors. In the study conducted by Balkıs et al. (2006), it was determined that the failure to manage time is one of the factors leading to academic procrastination.

In a study conducted by Milgram et al. (1993), it was concluded that there was no relationship between general procrastination and academic procrastination behavior, and academic procrastination was dependent on the situation of avoiding the task or avoiding the boredom of the task.

This research; It is considered important in terms of recognizing the students who succeeded below their potential due to their delaying habits and who have been subjected to various losses and to make these students more planned, programmed and productive. The ability of universities, which aim to provide qualified labor force to the country, to continue the education process in a qualified manner is also related to the fulfillment of the academic duties and responsibilities of the students on time. In Turkey, the discovery that there is a relationship between the general and academic procrastination for not doing enough of this subject are expected to contribute to the literature.

Method. The data collected through the quantitative method allowed for a more in-depth study of the research topic. (Green vd., 2005). The universe of the study is the students of Anadolu University in Eskişehir 
in 2018-2019 academic year. The sample (Kothari, 2004: 72), which is thought to represent the universe, is the 1st and 2nd year students (140 volunteers) of the Office Management and Executive Assistant and the Department of Real Estate and Real Estate Management of the Eskişehir Vocational School. The data were collected from the students in the specified sections according to random sampling method. In the research, "Academic Procrastination" and "General Procrastination" scales, whose validity and reliability have been proved by Çakıcı (2003), were used.

The Cronbach Alpha internal consistency coefficient of 19 items on the academic deferral scale was calculated as 0.82 . The cronbach Alpha internal consistency coefficient of 18 items on the general snooze scale was also found to be 0.82 . Since the reliability of the data is above the lower limit of 0.70 (Nunnally, 1978: 245), the data used has been found to be reliable.

In order to measure the normal distribution of the obtained data, Kolmogov-Smirnov (K-S) test was performed and the compatibility of the distribution to a theoretical distribution was tested (Ural \& Kılıç, 2013: $285)$. The $p$ value $(p<0.05)$ was calculated as 0.000 . On Likert-type scales it is stated that this result is normal (Saruhan \& Özdemirci, 2011: 175). Then the histogram and Q-Q graphs for the data were examined and the distribution was found to be close to the normal distribution. In the light of the results obtained, arithmetic average, mode and median values closer to each other, the value for skewness and kurtosis values show deviation from normal, the sample distribution approaches normal distribution when the number of volumes the adoption of more than 30 (Saruhan \& Özdemirci, 2011: 174) has decided to apply parametric tests due to.

Findings and discussion. This section contains the findings of the research. The demographic variables covered are age, gender, marital status, class, department, working status, and income level. There are 140 students included in the research. Participants in the 17-25 age range make up $94.3 \%$ of the entire group. Considering the data collected from the university students, it is expected that the majority will be in this group. By gender, $46.4 \%$ of the students were female and $53.6 \%$ were male. $1.4 \%$ of students are married while $98.6 \%$ are single. 1st. Grade students made up $61.4 \%$ of the entire group, 2. Students in the class make up $38.6 \% .57 .1 \%$ of the students were from office management and Executive Assistant, and $42.9 \%$ were from real estate and Real Estate Management. The proportion of students working in the whole group is $15 \%$. The income levels of the students are $34.3 \%$ for TL 500 and less, 39.3\% for TL 501-1000, 11.4\% for TL 1001$1500,5.0 \%$ for TL $1501-2000,10.0 \%$ for 2001 and above.

The highest score on the academic deferral scale is 95 and the lowest is 19. A high score on the scale indicates that students have a high level of academic deferrals. On the overall snooze scale, the highest score is 90 and the lowest score is 18. High scores from the scale indicate that people have a high level of general procrastination tendency.

According to Pearson correlation test data, there is a significant correlation between academic deferral trends and general deferral trends among students $(\mathrm{p}<0.01)$. There is a high level and positive relationship between academic and general procrastination tendency $(\mathrm{r}=0.74)$.

According to the independent sample t-test results, the students ' general and academic disposition levels do not differ significantly according to gender, marital status, working status, age and income level $(\mathrm{p}>0.05)$.

According to the results, the general and academic tendency levels of the students differ significantly according to class and Department $(\mathrm{p}<0.05)$. According to averages; 2. Average grade students, 1 . it is higher than the grade students. Students studying in the Department of real estate and property management have a higher average than those studying in the Department of office management and Executive Assistant.

Conclusion and recommendations. According to the analysis, the students ' overall and academic deferral scores are higher than the average score. Since the averages seem to be close together, students can be said to have a general and academic tendency to defer. This result overlaps with the research results of Ellis and Knaus (1977), Solomon and Rothblum (1984), and Ferrari and Scher (2000).

According to the data, there is a significant, high level and positive relationship between students ' academic deferral tendencies and general deferral tendencies. This results coincide with the work of Milgram and Tenne (2000), as well as the work of Kagan (2009) and Smurf (2011) where they conclude that an individual exhibiting general procrastination behavior will also exhibit academic procrastination behavior; or 
vice versa, a person exhibiting academic procrastination behavior will also exhibit general procrastination behavior.

The independent sample t-test was applied to determine whether students ' general and academic deferral tendencies differed by gender, marital status, class, department, and working status. The results of the study, which were obtained in various studies and determined that there was no relationship between gender and procrastination (Aydoğan, 2008; Gülebağlan, 2003; Özer \& Altun, 2011; Watson, 2001), are parallel with the results of this study.

The general and academic tendency levels of the students differ significantly by class $(\mathrm{p}<0.05)$. This coincides with the conclusion that the mean for procrastination behavior, achieved in research conducted by Doğan et al (2015), increases as the grade level increases.

The general and academic tendency levels of the students differ significantly according to the Department ( $\mathrm{p}<0.05)$. This result (Arikan, 2016) is in line with the research results. Different departments and, depending on this, more or less homework, applications, exams or projects affect the display of academic postponement behavior.

In Kagan's (2009) research on variables that he thinks are associated with academic postponement, the time management variable was identified as the most powerful factor that predicts academic postponement after general postponement. Having time management competencies, i.e. planning, regulation and control are important factors for an effective management process that will enable individuals to achieve their goals and succeed. Studies have shown that individuals with high procrastination tendency are not able to use time effectively and that academic procrastination behavior is high in individuals with low propensity to control, regulate and evaluate time (Balkis et al., 2006; Kagan, 2009). Sarikaya-Aydin and Koçak (2016) concluded that as time management skills of students increase, their tendency towards academic deferral behavior decreases.

Students who demonstrate academic deferral behavior because they cannot use time effectively can continue their academic tasks with effective time management and move away from deferral behavior. For this reason, universities are advised to put time management courses in their curricula. It is also recommended that universities organize time management conferences or seminars for their lecturers and that lecturers be trained to coach and mentor students in this direction.

As individuals who are unable to use time effectively and exhibit delaying behavior face problems such as inability to complete the work they started, neglect some tasks and responsibilities required by their work, family and social lives, and loss of productivity (Ekşi et al., 2019: 730) universities should organise events to raise students ' awareness of social media addiction. On the other hand; there is a meaningful relationship between nomophobia in general and general procrastination (Mert \& Akin, 2018). Accordingly, it is also recommended that universities raise students ' awareness of nomophobia, which is caused by the inability to use time efficiently and can cause many problems in everyday work or important work.

In addition, it is also suggested that courses such as ethics and professional ethics should be included in all educational programs. Because increasing awareness of concepts such as moral values, moral codes, honesty, respect, honor, responsibility will also reduce academic deferral behavior. Because, in the study of Ayy1ld1z (2016), it was revealed that the most important independent variable affecting general postponement and academic postponement were values. Later, researchers who will conduct research on this subject may be advised to examine the subject in depth with qualitative research.

Keywords: General procrastination, Academic procrastination, University students.

Öz: Amaç: Erteleme davranışı bireyin amaçlarına ulaşmasını geciktiren hatta engelleyen bir davranış olarak dikkat çekmektedir. Öğrencilerin genel erteleme davranışlarının akademik erteleme davranışına etkisinin olabileceği düşüncesi konuyu araştırmaya değer kılmaktadır. Bu nedenle çalışmanın amacı; üniversite öğrencilerinin genel ve akademik erteleme davranışlarını ve bu iki davranışın ilişkisini ortaya koymak şeklinde belirlenmiştir. "Üniversite öğrencilerinin genel erteleme davranışları ile akademik erteleme davranışları arasındaki ilişki nasıldır?" sorusu temel araştırma sorusu olarak belirlenmiştir. Yöntem: Araştırmanın örneklemini Anadolu Üniversitesi Eskişehir Meslek Yüksekokulu'nun Büro Yönetimi ve Yönetici Asistanlığı 
ve Emlak ve Emlak Yönetimi Bölümü 1. ve 2. Sınıf öğrencileri (140 gönüllü) oluşturmaktadır. Nicel araştırma yöntemiyle tasarlanan araştırmada veriler belirtilen bölümlerdeki öğrencilerden tesadüfi örnekleme yöntemine göre toplanmıştır. Araştırmada Çakıcı (2003) tarafından geçerliği ve güvenirliği kanıtlanmış olan "Akademik Erteleme" ve "Genel Erteleme" ölçekleri kullanılmıştır. Verilerin sonuçları çeşitli bilimsel yöntemler yardımıyla analiz edilerek genel veğ akademik erteleme eğilimi arasındaki bağ ve etki ortaya çıkarılmaya çalışılmıştır. Sonuç: Yapılan analizler sonucunda öğrencilerin genel ve akademik erteleme eğilime sahip oldukları ortaya çıkmıştır. Elde edilen verilere göre öğrencilerin genel ve akademik erteleme eğilimleri arasında anlamlı, yüksek düzeyde ve pozitif bir ilişki bulunmaktadır. Bu sonuç genel erteleme eğiliminde olan bireyin akademik erteleme eğiliminin de olacağı; ya da tersi akademik erteleme davranışı gösteren bir kişinin genel erteleme davranışını da göstereceği şeklinde yorumlanabilir.

Anahtar Kelimeler: Genel erteleme eğilimi, Akademik erteleme eğilimi, Üniversite öğrencileri

\section{Giriş}

Genel bir problem olması nedeniyle erteleme eğilimi her yaştan her meslekten milyonlarca insanı etkileyen yaşamın her alanında görülebilen, bireyleri ve örgütleri etkileyen bir sorundur. Bilimsel olarak erteleme ya da geciktirme davranışının incelenmeye başlaması 1990'ların sonuna denk gelmektedir. Demografik özellikleri farklı olan pek çok kişi işlerini son dakikaya bırakma davranışı gösterebilir ancak bilimsel araştırmalar erteleme davranışının soy, itikat ya da etnik kökene göre bir değişiklik göstermediğini ortaya koymuştur (Burka\&Yuen, 1983; Ferrari\&Beck, 1998). Başarı ve üretkenlik değerlerinin giderek önem kazandığı günümüzde bir yandan da başarılması ya da üretilmesi gereken hedeflerin ertelendiği ya da geciktirildiği görülmektedir.

Davranışçı yaklaşıma göre erteleme; erteleyen birey geçmiş yaşantısında, erteleme davranışı pekiştirildiği için (Yıldırım, 2014) hatta bu davranışından dolayı ödüllendirildiği için ya da hak ettiği ceza verilmediği için öğrenilmiş bir alışkanlık haline gelmektedir. Erteleme; bireylerin spor etkinlikleri, gezi, müzik dinleme vb. keyif veren eylemlere yönelmeleri ya da uzun vadeli ödüller yerine, örneğin internette sörf yapma gibi kısa vadede erişilecek ödüllerin yeğlenmesi nedeniyle yapılmaktadır (Özdemir, 2012; Topal, 2015; Uzun\&Demir, 2015).

Psikodinamik kuramlar ise ertelemeyi bireyin çok yüksek başarı çıtası koyan ebeveynlere ya da aşırı hoşgürülü ebeveynlere yönelik bir başkaldırı ya da başarısızlık endişesiyle işi yarım bırakarak kaygıdan kaçma, bir eylem egoyu tehdit ettiği için erteleyerek kaçınma eylemi olduğunu öne sürmektedir (Tice\&Baumeister, 1997).

Bilişsel yaklaşıma göre ise gerçekçi olmayan inançlar, korkular, kişinin kendine dönük eleştirileri, en iyisini yapma isteği ve başarısızlık korkusu hissetme nedeniyle bir girişimde bulunmayarak özsaygıyı koruma isteği, düşük özyeterlik algısı (Gün vd., 2019), özdeğerliliği koruma amacı, mükemmelliyetçilik (Vestervelt, 2000; Topal, 2015; Yıldırım, 2014) gibi faktörler ertelemeye neden olabilmektedir. Beş büyük kişilik özelliği olarak tanımlanan; açıklık, sorumluluk, dışa dönüklük, duygusal denge(sizlik) ve uyumluluk ile akademik erteleme arasında anlamlı ilişkilerin olduğuna dair sonuçlar elde edilen araştırmalar vardır (Çam, 2013; Karataş\&Bademcioğlu, 2015).

Milgram (1992) modern çağda erteleme davranışının bir sorun olduğunu vurgulayarak gelişmiş teknolojiye sahip toplumlarda ortaya çıktığını öne sürmektedir. Ancak erteleme yalnızca çağcıl bir sorun değildir, endüstriden önceki topluluklarda da erteleme davranışının olduğu eski Mısırda da tembellik etmenin zararlı bir alışkanlık olarak tanımlandığı bilinmektedir. Latince metinlerde ise anlaşmazlıkların giderilmesinde gerekli dayançın sergilenmesi anlamında kararları ertelemenin makul ve lüzumlu bir davranış olacağı görüşü bulunmaktadır (aktaran Çakıcı, 2003: 3) Böylelikle yeterli bilgi ve öngörüye sahip olunmayan durumlarda acele karar vermemek anlamında kullanılmıştır. Stratejik erteleme olarak tanımlanabilecek olan bu durum; bir bilgiyi ya da herhangi bir şeyi elde etmeye yönelik, ulaşılmak istenene çözümün ve amacın bir parçası olan geciktirmelerdir (Knaus, 2000) ve bu çalışma kapsamında yer almamaktadır. 


\section{Kavramsal Çerçeve}

İngilizcede erteleme kavramı procrastination sözcüğü ile ifade edilmekte ve bir işi farklı bir güne, ileriye sarkıtmak anlamına gelmektedir. Literatürde farklı araştırmacılar tarafından yapılmış çeşitli erteleme tanımları bulunmaktadır:

- Erteleme; yapılması gerekli ve öncelikli bir eylemi lüzumsuz olarak geciktirmek ya da son dakikaya birakmaktır.

- Erteleme öz kontrol performansının eksikliği ya da bulunmamasıdır.

- Erteleme hedeflere ulaşmayı ertelemedir.

- Erteleme yapılması gereken bir işin gerekenden fazla zamanda yapılması, uzun sürmesidir.

- Erteleme işi ağırdan alma, oyalanmadır.

- Erteleme bireyin bir konuda alacağı kararı veya yapacağı işi geciktirmesidir (Sirois, 2007).

- Erteleme mantıki/önemli bir sebep olmadan yapılması gerekli bir işi ileri bir zamana birakmaktır (Schouwenburg\&Lay, 1995).

Literatürde erteleme; bireyin yaşamın pek çok alanında ertelemeye yatkın olduğu bir kişilik özelliği, davranışsal yatkınlık şeklinde (Milgram\&Tenne, 2000) ya da karar verme becerilerinden yoksun olma nedeniyle (Milgram\&Toubiana, 1999) karar vermekten kaçınma şeklinde nitelendirilmektedir. Erteleme; sorumluluk alma konusundaki isteksizlikten dolayı ortaya çıkabildiği gibi sosyal medyada zaman harcayarak işten kaçınma nedeniyle de gerçekleşebilir. Kandemir (2010) ertelemeyi; çekinmek ve çekinilen işi ileride yapacağına ilişkin kendi kendine söz vermek ve gecikme hakkında kendini doğrulamak için sebepler bulmak olarak tanımlamaktadır. Buna göre; kişi harekete geçecek yeterlikte olmadığını hissettiğinde erteleme davranışı gösterebilmektedir. Johnson ve Bloom (1992) ise ertelemenin bir takım psikolojik belirtilerle bağlantılı olabileceğini düşünerek bu hipotezi sınamak için kliniğine ilk kez başvuran 160 hasta üzerinde bir araştırma yapmıştır. Bu araştırma neticesinde erteleme davranışla kaygı, depresyon, madde kullanımı ve fobiler arasında ilişki olduğu sonucuna ulaşmıştır.

Ertelemenin bilişsel, duyuşsal ve davranışsal boyutlarından söz edilebilir. Bilişsel boyut açısından ele alınırsa; ertelemeci bireyin amaç ve öncelikleriyle performansı arasında uyumsuzluk söz konusudur. $\mathrm{Bu}$ durum işlerin önem ve önceliklerini ayırt edememesinden kaynaklanabilir. Duyuşsal boyut açısından ele alınırsa; erteleme davranışı gösteren bireyin bu davranışından dolayı bask1, stres (Sirois\&Tosti, 2012) gibi duygular hissetmesi söz konusudur. Eğer erteleme bireyde böyle bir duyguya yol açmıyorsa zaten erteleme söz konusu değildir. Ancak unutmamak gerekir ki hissedilen rahatsızlık özneldir. Davranı̧sal boyut açısından ele alınırsa; erteleme bir bireyin zaman zaman veya nadiren gösterdiği bir davranışsa bu alışkanlık düzeyinde bir eğilim değildir ancak birey oyalanmayı, bir işe başlamayı, devam ettirmeyi ve bitirmeyi erteleme davranışını alışkanlık haline getirdi ise kronik bir durum söz konusudur.

Chu \&Choi (2005) erteleme eğiliminde olan kişileri, etkin ve edilgen erteleyiciler şeklinde iki ye ayırmaktadır. Edilgen erteleyiciler; kognitif erteleme eğilimi göstermeyen ancak hızlıca karar verip uygulamaya geçiremeyen ve bu nedenle görev ve sorumluluklarını erteleyen, etkin erteleyiciler ise farklı uğraşlar içinde olmak istedikleri için ertelemeci davranan kişiler olarak ifade edilmektedir. Burka ve Yuen'e (1983) göre bireyler erteleme sürecinde Şekil 1 deki gibi bir döngüye girmektedirler. Bu erteleme döngüsü kısa ya da uzun süreli olabilmektedir. 


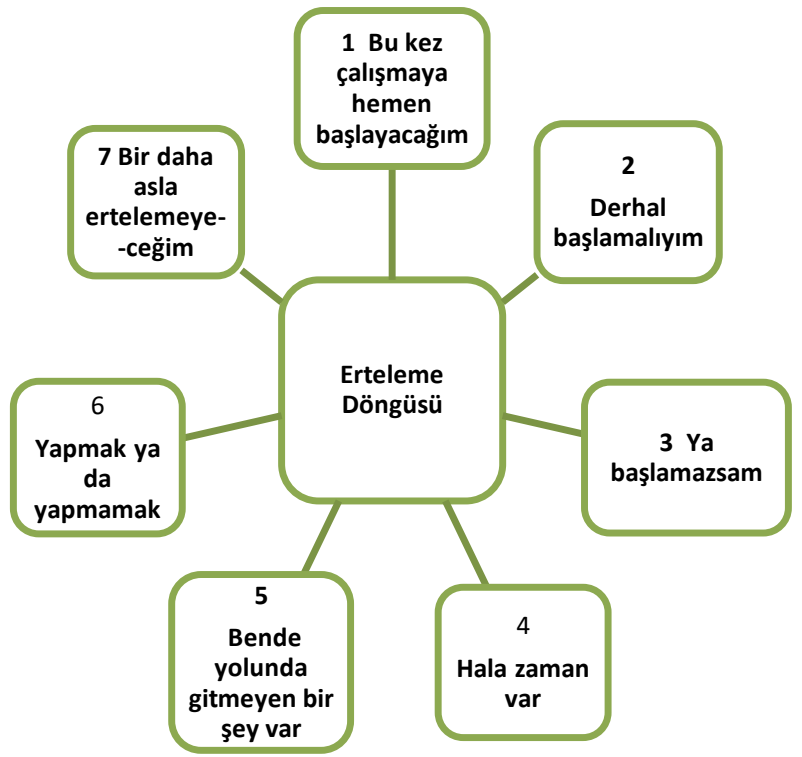

Şekil 1. Erteleme Döngüsü

Ertelemenin; gecikme cezası ödeme gibi küçük ya da bir hakkı kaybetme gibi büyük dışsal bedelleri olabildiği gibi bireyin pişmanlık, çaresizlik duyması gibi içsel bedelleri de olabilmektedir. Döngünün 6.basamağında olan kişi çok yüksek gerilim altına girmekte ve esasen artık işi tamamlamak imkânsız görünmektedir. Birey bu noktada işi tamamlamaktan vazgeçebildiği gibi işi tamamlama eylemine de girişebilmektedir. Sonuçta; işi tamamlayamayacağını düşünerek vazgeçen birey de tüm gecikmeye rağmen tamamlayabilen bireyde bir iç huzura kavuşmakta ve bir daha böyle bir döngüye girmemek için planlı ve zamanında çalışmaya başlamaktadır.

Saddler ve Sacks (1993) ertelemeyi genel ve akademik erteleme olarak sınıflandırmışlardır. Milgram ve Toubiana (1999) bireyin gerçekleştirmesi gerekli olan bir işi erteleme davranış1 göstermesinin sistematik alışkanlık veya süreğen bir davranış kalıbı olması durumunda genel erteleme olarak adlandırılabileceğini belirtmiştir. Akademik erteleme ise bireyin yaşamının yalnızca bir alanında gösterdiği durumsal erteleme davranışı türüdür. Milgram ve Marshevsky (1995) akademik ertelemenin boyutlarını şöyle sıralamışlardır:

- Davranışsal erteleme,

- $\mathrm{Bu}$ ertelemeden ötürü bireyin duygusal karışıklığa girmesi,

- Görevlere yönelik gönülsüzlük,

- Görevin yapılabilmesi hakkında anlama ve kavrama yeteneği ve

- Erteleme eylemini azaltma isteği.

Akademik erteleme neredeyse her zaman akademik görevlerin ertelenmesi ve neredeyse her zaman bu konuda kaygı hissedilmesi olarak tanımlanmakta ve teslimi yaklaşan bir işin son ana ertelenmesi veya hemen sınav öncesi ders çalışılması gibi davranışlarla örneklenmektedir (Ferrari, 1991). Burada akademik görevlerin bilincinde ancak amaçsızca, başlamanın veya bitirmenin ertelenmesi söz konusudur. Uzmanlar lisans öğrencilerinin akademik erteleme davranışlarıyla ilgili yaptıkları araştırmada (Ellis\&Knaus, 1977; Ferrari vd., 2005) öğrencilerin yaklaşık \% 70'inin akademik erteleme davranışı sergilediğini bulgulamışlardır. Yine üniversite öğrencilerinin incelendiği bir çalışmada (Solomon\&Rothblum, 1984) \%46'sının ödev/poje yazma konusunda \% 30 'unun haftalık okumaları yapma konusunda, \% 28 'inin sınava hazırlanma konusunda, \% 23 'ünün 
ders devamlılığı konusunda ve \% 11'inin de öğrenim harcı ödeme gibi idari işleri yerine getirmede ertelemeci davrandıkları tespit edilmiştir. Türkiye'de yapılan benzer araştırmalarda ise bu oranın daha düşük seviyede \%50-\%60 arasında yer aldığı görülmektedir (Özer, 2007). Ferrari ve Scher'in (2000) lisans öğrencileriyle yaptıkları diğer bir araştırmada ise katılımcçıların hem ödev, sunum hazırlama gibi akademik görevleri hem de ev temizliği ve spor gibi görevleri erteledikleri belirlenmiştir.

He'nin (2017) yaptığı bir araştırmanın sonuçlarına göre akademik erteleme nedenleri ise dersin zorluğu, dersin çokluğu ve eğitmenlerin tutumları gibi ders ile ilgili nedenler ile bireysel ve sosyal nedenlerdir. Bunlar; stres ve sağlık problemleri, motivasyon ve disiplin eksikliği, tembellik, aşırı özgüven ya da özgüven eksikliği, başarısızlık korkusu (Yazıcı vd. 2009) sabırsız olma, ilgisiz olma, başkalarını sömürme alışkanlığı (Gün, 2010) değerlerin ve amaçların net olmaması, umutsuzluk (Odacı\&Kaya, 2019; Dünyaoğulları, 2011; Yıldız\&Yıldız, 2016), dikkat dağınıklığı ve organizasyon becerisine sahip olmama (Flett vd., 1995) ve mükemmelliyetçi kişilik özellikleri, olumsuz akran etkileri ve rol model eksikliği şeklinde sıralanabilir.

Akademik ertelemenin sonuçları açısından ise ertelemenin işlerin birikmesine, zaman baskısına, gecikmelere, kalitesiz işlere ve bilgi eksikliğine yol açtığı ve dersi ya da okulu bırakmaya neden olduğunu ortaya konulmuştur. Özel yaşam boyutunda ise akademik erteleme ekonomik kayıplara ve sosyal ilişki problemlerine yol açmaktadır. Akademik erteleme davranışının, bireyin duygusal zekâ düzeyiyle diğer bir ifade ile bireyin kendisinin ya da diğerlerinin duygularını anlama, sezme, yönetme ve yönlendirme yetisiyle de bağlantılı olduğu farzedilmektedir. Grunschel ve arkadaşlarının (2013) araştırmaları ise akademik ertelemenin zihinsel ve fiziksel boyutta uyku problemlerine ve fiziksel gerilime yol açtığını göstermiştir. Aynı araştırma; akademik ertelemenin duygusal boyutta ise endişe ve kaygı, bıkkınlık, utanç vb. duygulara yol açtığını da göstermiştir. Aydoğan\&Özbay (2012) ve Ekşi\&Dilmaç (2010)'ın çalışmalarında da erteleme davranışının endişe ve kaygıya yol açtı̆̆ 1 sonucuna ulaşılmıştır. Ferrari\&Beck (1998)'e göre utanç duygusu daha çok ertelemecilerin ertelemeleri ile ilgili gerçekçi bir mazerete sahip olmadıklarında ortaya çıkmaktadır. Grunschel ve arkadaşlarının (2013) araştırması aynı zamanda akademik ertelemenin kişilik boyutunda olumsuz benlik algisına neden olduğunu da ortaya koymuştur. Ülkemizde Aydoğan (2008), Kandemir (2010), Aydoğan\&Özbay (2012) tarafından yapılan araştırmalar benlik saygısı düşük olan bireylerin erteleme eğilimlerinin daha yüksek olduğunu ortaya koyarken, kendini baltalama (Akça, 2012), kendinden şüphe etme (Duru\&Balkıs, 2014), usçu olmayan öğretiler ve olumsuz değerlendirilme çekincesi (Çelik\&Odacı 2015), bunalım, üzüntü ve stres seviyeleri (Deniz\&Akdoğan, 2014) ile erteleme eğilimi arasında pozitif ve anlamlı ilişki olduğu bulgulanmıştır. Öte yandan akademik ertelemeyle yetkinlik beklentisi (Çelik\&Odac1, 2015), özgüvenli olma (Yeşil\&Şahan, 2012), özsaygı (Kandemir vd., 2014), stresle başa çıkabilme (Kandemir, 2014), sorumluluk sahibi olma (Bulut, 2015), yetkin olma inancı (Çelikkaleli\&Akbay, 2013) ve uyumluluk (Deniz vd., 2009) arasında negatif ve anlamlı ilişki olduğu belirlenmiştir. Işık (2019) gerçekleştirdiği araştırmada, zarar görmüş özerklik/başarısızlık ve kopukluk/reddedilmişlik şema ekseninde değerlendirildiğinde; kişilik, kimlik gelişimi zarar gören bireylerde erteleme eğiliminin daha çok görüldügünü gözlemlemiştir.

Yapılan çalışmalar, akademik ortamda sıklıkla sergilenen erteleme davranışının akademik başarısızlık nedenlerinin en önemlilerinden biri olduğunu göstermiştir (Schouwenburg vd., 2004; Akinsola vd., 2007; Beswick vd., 1988; Wang\&Englander, 2010; Orpen, 1998; Rothblum vd., 1986). Akademik erteleme davranışı, duygusal olarak bireyi yıpratmakta ve devam eden bu davranış biçimine bağlı olarak öğrenciler derslerden düşük not almakta ve başarısız olmaktadırlar (Beck vd., 2000; akt. Deniz vd., 2009). Türkiye'de yapılan araştırmalarda da akademik erteleme davranışıyla akademik başarını iliş̧isinin negatif yönlü ve anlamlı olduğu sonucuna ulaşılmıştır (Akkaya, 2007; Bulut, 2015; Çetin, 2009). Birçok araştırmada akademik ertelemenin genel olarak öğrencilerin intihal 
gibi akademik sahtekarlıklara yol açtığını rapor etmiştir (Klassen vd., 2008; Patrzek vd., 2015, Sirois vd., 2003).

Öğrenim görülen bölümlerin eğitsel alan farklılığı sonucunda bölümlerin ödev, uygulama, sınav ya da proje sayısı akademik erteleme davranışının görülmesini etkileyebilmektedir (Balkıs, 2007, akt. Çelik\&Odacı, 2015). Araştırmalar zaman yönetimi konusunda yetersizliğin de erteleme eğilimini artırdığı ortaya koymuştur (Milgram vd., 1995; Orpen, 1998; De Raad, 2000). Türkiye'de Sarıkaya-Aydın ve Koçak'ın (2016) yaptıkları araştırma; öğrencilerin zaman yönetimi becerileriyle akademik erteleme davranışları ilişkisinin negatif yönde, orta seviyede, anlamlı olduğunu ortaya koymuştur. Balkıs ve arkadaşlarınca (2006) yürütülen bir yapılan araştırma da zamanı yönetememenin akademik ertelemeye yol açan faktörlerden biri olduğu belirlenmiştir.

Milgram ve arkadaşlarının (1993) yaptıkları araştırmada ise genel ve akademik erteleme davranışının ilişkili olmadığı, akademik ertelemenin görevden kaçınma veya görevin sıkıcılığından kaçınma durumuna bağlı olduğu sonucu elde edilmiştir. Milgram ve arkadaşlarının yaptıkları diğer bir (1998) araştırmada ise öğrencilerin ve bu öğrencilerin annelerinin öğrencilik dönemi akademik ve genel erteleme davranışları arasında ilişki olduğu bulunmuştur. Bu öğrencilerin babaların genel erteleme davranışları ile öğrencilik dönemi akademik erteleme davranışlarının da ilişkili olduğu sonucu elde edilmiştir.

$\mathrm{Bu}$ araştırma; erteleme alışkanlıkları nedeniyle potansiyellerinin altında başarı gösteren ve bu nedenle çeşitli zararlara mağdur kalan öğrencilerin ayırt edilebilmeleri ve planlı, programlı ve üretken olabilmeleri için desteklenmeleri açısından önemlidir. Ülkeye nitelikli işgücü kazandırmayı amaçlayan üniversitelerin öğrenim sürecini kaliteli olarak yürütebilmeleri, öğrencilerin akademik görev ve sorumluluklarını zamanında gerçekleştirmeleriyle de ilişkilidir. Türkiye'de bu konunun yeterince araştırılmamış olması nedeniyle genel ve akademik erteleme eğiliminin ilişkili olup olmadığının saptanmasının literatüre katkı sağlayacağı umulmaktadır.

\section{Araştırma Yöntemi}

\section{Evren ve Örneklem}

Nicel yöntem aracılığıyla toplanan veriler birçok katılımcıya ulaşmayı sağlarken; gözlem, görüşme gibi nitel yöntemlerle sağlanan verilerin, araştırma konusunu daha derinlemesine incelenme olanağ1 sunacağ1 düşünülmektedir (Green vd., 2005). Bu nedenle nicel bir araştırma olarak hazırlanan çalışmada evren 2018-2019 öğretim yılında Eskişehir ilinde yer alan Anadolu Üniversitesi öğrencileri olarak belirlenmiştir. Bu araştırmada incelenen, hakkında fikir sahibi olunmak istenen, aktif olarak araştırılan ve evreni temsil ettiği düşünülen örneklemi (Kothari, 2004:72) ise Anadolu Üniversitesi Eskişehir Meslek Yüksekokulu'nun Büro Yönetimi ve Yönetici Asistanlığ ve Emlak ve Emlak Yönetimi Bölümü 1. ve 2. Sınıf öğrencileri (140 kişi) oluşturmaktadır. Veriler belirtilen bölümlerdeki öğrencilerden tesadüfi örnekleme yöntemine göre toplanmıştır.

\section{Veri Toplama}

Kullanılan Araçlar. Araştırmada, öğrencilerin akademik erteleme davranışları Çakıcı (2003) tarafından geçerliği ve güvenirliği kanıtlanmış olan “Akademik Erteleme Ölçeği” ile öğrencilerin genel erteleme davranışları ise yine Çakıcı (2003) tarafından geçerliği ve güvenirliği kanıtlanmış olan "Genel Erteleme Ölçeği” ile belirlenmiştir. Araştırmada, bu ölçekler Çakıcı'nın (2003) çalışmasında olduğu gibi tek boyutlu olarak kullanılmıştır.

Prosedür/İşlemselleştirme. Araştırma verileri üniversite öğrencisi olan Anadolu Üniversitesi Eskişehir Meslek Yüksekokulu'nun Büro Yönetimi ve Yönetici Asistanlığı ve Emlak ve Emlak Yönetimi Bölümü 1. ve 2. Sınıf öğrencileridir. Nicel araştırma yöntemiyle tasarlanan araştırmanın verileri istatistiksel analiz programları yardımıyla analiz edilmiştir. Araştırmanın çalı̧̧ma grubunu 140 gönüllü öğrenci oluşturmaktadır. 


\section{Araştırmanın Modeli ve Hipotezleri}

$\mathrm{Bu}$ araştırmada öğrencilerin genel erteleme davranışlarının akademik erteleme davranışına etkisinin olabileceği düşüncesi konuyu araştırmaya değer kılmıştır. Bu nedenle çalışmanın amacı; üniversite öğrencilerinin genel ve akademik erteleme davranışlarını ve bu iki davranışın ilişkisini ortaya koymak şeklinde belirlenmiştir. "Üniversite öğrencilerinin genel erteleme davranışları ile akademik erteleme davranışları arasındaki ilişki nasıldır" sorusu temel araştırma sorusu olarak belirlenmiş, aşağıdaki hipotezler test edilmiştir:

H1: Öğrencilerin genel ve akademik erteleme eğilimleri arasında anlamlı bir ilişki vardır.

H2: Öğrencilerin genel erteleme eğilimi düzeyleri demografik özelliklere göre anlamlı ölçüde farklılaşmaktadır.

H3: Öğrencilerin akademik erteleme eğilimi düzeyi demografik özelliklere göre anlamlı ölçüde farklılaşmaktadır.

\section{Analiz ve Bulgular}

\section{Veri Analizi}

Her iki ölçekteki maddelerin puanlandırılması şu şekilde olmuştur: Beni tamamen yansıtıyor seçeneği 5, beni genellikle yansitıyor seçeneği 4 , beni az yansitıyor seçeneği 3, beni çok az yansitıyor seçeneği 2 ve beni yansıtmıyor seçeneği 1 olarak kodlanmıştır. Akademik Erteleme Ölçeğinden alınabilecek puanlar 95-19 aralığındadır. Ölçekten alınan puanın yüksekliği, akademik ertelemelerinin yüksek düzeyde olduğunu ifade etmektedir. Genel Erteleme Ölçeğinden alınabilecek puanlar ise 90-18 aralığındadır. Ölçekten alınan puanın yüksekliği bireylerin genel erteleme eğiliminin yüksek düzeyde olduğunu göstermektedir.

Veri güvenirliklerini test etmek amacıyla Cronbach Alfa katsayısından yararlanılmıştır. Alfa katsayısı, ölçekteki maddelerin iç tutarlılık ölçüsüdür (Alpar, 2010: 350). Akademik Erteleme Ölçeğinde yer alan 19 maddenin Cronbach Alfa iç tutarlılığ 10,82 dir. Genel Erteleme Ölçeğindeki18 maddenin Cronbach Alfa iç tutarlılık katsayısı da 0,82 dir. Bu durum veri güvenilirliğinin, kabul edilen alt sınırın $(0,70)$ üstünde olduğunu açılamaktadır (Nunnally, 1978: 245). Bu nedenle araştırma verileri, güvenilirdir, denilebilir.

\section{Bulgular}

Araştırmada elde edilen ve katılımcıların demografik özelliklerini gösteren bulgular Tablo 1 'de verilmiştir. Ele alınan demografik değişkenler yaş, cinsiyet, medeni durum, sınıf, bölüm, çalışma durumu ve gelir düzeyidir. 
Üniversite Öğrencilerinin Genel Erteleme Davranışları ile Akademik Erteleme Davranışları... 1207

\begin{tabular}{|c|c|c|c|}
\hline \multicolumn{4}{|c|}{ Tablo 1: Öğrencilerin Demografik Özellikleri } \\
\hline Değişkenler & & $\mathbf{n}$ & $\%$ \\
\hline \multirow{3}{*}{ Yaş } & $17-25$ & 132 & 94,3 \\
\hline & $26-35$ & 6 & 4,3 \\
\hline & 36 ve üstü & 2 & 1,4 \\
\hline \multirow{2}{*}{ Cinsiyet } & Kadın & 65 & 46,4 \\
\hline & Erkek & 75 & 53,6 \\
\hline \multirow{2}{*}{$\begin{array}{l}\text { Medeni } \\
\text { Durum }\end{array}$} & Evli & 2 & 1,4 \\
\hline & Bekâr & 138 & 98,6 \\
\hline \multirow{2}{*}{ Sinıf } & 1. Sinif & 86 & 61,4 \\
\hline & 2. Sinif & 54 & 38,6 \\
\hline \multirow{2}{*}{ Bölüm } & Büro Yönetimi ve Yönetici Asistanlığ & 80 & 57,1 \\
\hline & Emlak ve Emlak Yönetimi & 60 & 42,9 \\
\hline \multirow{2}{*}{$\begin{array}{l}\text { Çalışma } \\
\text { Durumu }\end{array}$} & Çalışan & 21 & 15,0 \\
\hline & Çalışmayan & 119 & 85,0 \\
\hline \multirow{5}{*}{ Gelir Düzeyi } & 500 € ve daha az & 48 & 34,3 \\
\hline & 501-1000 & 55 & 39,3 \\
\hline & 1001-1500‡ & 16 & 11,4 \\
\hline & $1501-2000 €$ & 7 & 5,0 \\
\hline & 2001 € ve üstü & 14 & 10,0 \\
\hline
\end{tabular}

Araştırmada değerlendirme kapsamına alınan 140 öğrenci bulunmaktadır. 17-25 yaş aralığ1 katılımcılar tüm grubun \%94.3'ünü oluşturmaktadır. Verilerin üniversite öğrencisinden toplandığı düşünüldüğünde çoğunluğun bu grupta olması beklenilen bir durumdur. Cinsiyete göre öğrencilerin \% 46,4'u kadın, \%53,6'i erkektir. Öğrencilerin \%1,4'ü evli iken \%98,6'sı bekârdır. Sınıflara göre 1. Sınıf öğrencileri tüm grubun \%61,4'sini, 2. Sınıf öğrencileri ise \%38,6'sını oluşturmaktadır. Bölümlere göre incelendiğinde öğrencilerin \%57,1'i Büro Yönetimi ve Yönetici Asistanlığı, \%42,9'u Emlak ve Emlak Yönetimi bölümündendir. Tüm grupta çalışan öğrencilerin oranı \% 15 'tir. Öğrencilerin gelir düzeyleri ise $500 €$ ve daha az olanlar \%34,3, 501-1000 $€$ aras $\% 11,4,1501-2000 €$ aras $\%$ 5,0, $2001 €$ ve üstü \%10,0 şeklindedir.

\section{Normal Dağılım Testlerine İlişkin Bulgular}

Elde edilen verilerin normal dağ 11 lım gösterip göstermediğini ölçmek üzere KolmogovSmirnov (K-S) testinden yararlanılmıştır. K-S testi ile verilen bir dağılımın teorik bir dağılıma (normal, poisson dağılımı gibi) uygunluğu test edilmektedir (Ural\&Kılıç, 2013: 285). Yapılan analiz sonucunda $p$ değeri $(p<0,05) 0,000$ olarak hesaplanmıştır. Likert tipi ölçeklerde bu sonucun ortaya çımasının normal olduğu ifade edilmektedir (Saruhan\&Özdemirci, 2011: 175). Bu nedenle dağılımın normal dağılıma uygun olup olmadığına ilişkin görsel analizlerin yapılmasına karar verilmiştir. Buna göre verilere ilişkin histogram ve $Q-Q$ grafikleri incelenmiştir. Yapılan incelemelerin sonucunda dağılımın normal dağılıma yakın olduğu görülmüştür. Ayrıca, yapılan incelemelerin sonucunda verilerin mod, medyan ve aritmetik ortalama değerlerinin birbirine yakın olduğu tespit edilmiştir. Buna karşın, basıklık ve çarpıklık katsayıları da hesaplanarak analize dâhil edilecek verilerin $+1 /-1$ arasında değer aldığı bulunmuştur. Ayrı olarak, merkezi limit teoremine göre değişkenlerin normal dağılım sergileyip sergilemediklerine bakılmaksızın, örneklem sayısı yeterliyse, dağılımın normal olacağı kabul edilmektedir (Sekaran, 2003: 268; Tabachnick\&Fidell, 2007: 78). Elde edilen sonuçlardan hareketle; aritmetik ortalama, mod ve medyan değerlerinin birbirine yakın değerde olması, çarpıklık ve basıklık değerlerinin normalden sapma göstermemesi, örneklem birimi sayısının 30'un üzerine çıktığında dağılımın normal dağılıma yaklaştı̆̆ının kabul edilmesi (Saruhan\&Özdemirci, 2011: 174) nedeniyle parametrik testlerin uygulanmasına karar verilmiştir. 


\section{Bulgular}

Öğrencilerin Genel ve Akademik Erteleme Ölçeğinden Aldıkları Puanlara İlişkin

Tablo 2: Öğrencilerin Genel ve Akademik Erteleme Ölçeğinden Aldıkları Puanlara İlişkin Bulgular

\begin{tabular}{llll}
\hline & $\boldsymbol{n}$ & $\overline{\boldsymbol{x}}$ & S.S. \\
\hline $\begin{array}{l}\text { Akademik Erteleme } \\
\text { Ölçeği }\end{array}$ & 140 & 58,04 & 19,36 \\
\hline $\begin{array}{l}\text { Genel } \\
\text { Erteleme Ölçeği }\end{array}$ & 140 & 52,61 & 9,64 \\
\hline
\end{tabular}

Tablo 2 incelendiğinde genel ve akademik erteleme puanlarının ortalama puandan yüksek olduğu ve ortalamaların birbirine yakın olduğu anlaşılmaktadır. Bu doğrultuda, öğrencilerin genel ve akademik erteleme eğilime sahip oldukları söylenebilir.

Öğrencilerin Genel ve Akademik Erteleme Eğilimlerine İlişskin Pearson Korelasyon Testine İlişkin Bulgular

Öğrencilerin akademik erteleme eğilimleriyle genel erteleme eğilimleri arasında ilişki olup olmadığını ve varsa ilişkinin gücünü ve yönünü belirlemek üzere Pearson Korelasyon Testinden yararlanılmıştır.

Tablo 3: Öğrencilerin Genel ve Akademik Erteleme Eğilimlerine İlişkin Pearson Korelasyon Testine İlişkin Bulgular

\begin{tabular}{|c|c|c|c|c|c|c|}
\hline & & & $\begin{array}{l}\text { Genel } \\
\text { Eğilimi }\end{array}$ & Erteleme & $\begin{array}{l}\text { Akademik } \\
\text { Eğilimi }\end{array}$ & Erteleme \\
\hline \multirow{3}{*}{$\begin{array}{l}\text { Genel } \\
\text { Eğilimi }\end{array}$} & \multirow[t]{3}{*}{ Erteleme } & Pearson Korelasyonu & 1 & &, $740 * *$ & \\
\hline & & $\mathrm{p}$ & & &, 000 & \\
\hline & & $\mathrm{N}$ & & & 140 & \\
\hline
\end{tabular}

$* \mathrm{p}<, 01 ; \mathrm{p}<, 05$

Elde edilen verilere göre öğrencilerin akademik erteleme eğilimleri ile genel erteleme eğilimleri arasında anlamlı bir ilişki vardır $(\mathrm{p}<0,01)$. Akademik ve genel erteleme eğilimi arasında yüksek seviyede ve pozitif bir ilişki vardır $(\mathrm{r}=0,74)$. Dolayısıyla, genel erteleme davranışı sergileyen öğrencilerin akademik erteleme davranışı da sergileyeceği veya tam tersine akademik erteleme davranışı sergileyen öğrencilerin genel erteleme davranışını da sergileyeceği söylenebilir.

Öğrencilerin Genel ve Akademik Erteleme Eğilimlerinin Demografik Özelliklere Göre Farklılaşmasına Yönelik Bulgular

Öğrencilerin genel ve akademik erteleme eğilimlerinin cinsiyete, medeni duruma, sınıfa, bölüme ve çalışma durumuna göre değişiklik gösterip göstermediğini saptamak için bağımsız örneklem t-testi yapılmıştır.

Tablo 4: Öğrencilerin Genel ve Akademik Erteleme Eğilimlerinin Cinsiyete Göre Farklılaşmasına Yönelik Bulgular

\begin{tabular}{|c|c|c|c|c|c|c|c|}
\hline \multicolumn{2}{|c|}{$\begin{array}{l}\text { Erteleme } \\
\text { Eğilimleri } \\
\end{array}$} & Cinsiyet & $\mathbf{n}$ & $\bar{x}$ & s.s. & $\mathbf{t}$ & $\mathbf{p}$ \\
\hline \multirow{2}{*}{$\begin{array}{l}\text { Genel } \\
\text { Eğilimi }\end{array}$} & \multirow[t]{2}{*}{ Erteleme } & Kadın & 65 & 52,02 & 11,28 & \multirow{2}{*}{$-0,591$} & \multirow{2}{*}{0,556} \\
\hline & & Erkek & 75 & 53,13 & 11,07 & & \\
\hline \multirow{2}{*}{\multicolumn{2}{|c|}{$\begin{array}{l}\text { Akademik } \\
\text { Erteleme Eğilimi }\end{array}$}} & Kadın & 65 & 56,99 & 10,48 & \multirow[b]{2}{*}{$-1,023$} & \multirow[b]{2}{*}{0,308} \\
\hline & & Erkek & 75 & 58,95 & 11,99 & & \\
\hline
\end{tabular}


Üniversite Öğrencilerinin Genel Erteleme Davranışları ile Akademik Erteleme Davranışları... 1209

Elde edilen sonuçlara göre öğrencilerin genel ve akademik eğilim seviyeleri cinsiyete göre anlamlı bir farklılık göstermemektedir $(\mathrm{p}>0,05)$.

Tablo 5: Öğrencilerin Genel ve Akademik Erteleme Eğilimlerinin Medeni Duruma Göre

Farklılaşmasına Yönelik Bulgular

\begin{tabular}{lllllll}
\hline $\begin{array}{l}\text { Erteleme } \\
\text { Eğilimleri }\end{array}$ & $\begin{array}{l}\text { Medeni } \\
\text { Durum }\end{array}$ & n & $\bar{x}$ & s.s. & t & p \\
\hline Genel Erteleme & Evli & 2 & 61,00 & 12,73 & \multirow{2}{*}{1,072} & 0,285 \\
Eğilimi & Bekâr & 138 & 52,49 & 11,13 & & \\
\hline Akademik & Evli & 2 & 64,50 & 10,61 & \multirow{2}{*}{0,812} & 0,418 \\
Erteleme Eğilimi & Bekâr & 138 & 57,94 & 11,34 & & \\
\hline
\end{tabular}

Tablo 5 incelendiğinde öğrencilerin genel ve akademik eğilim düzeyleri medeni duruma göre anlamlı bir farkl1l1k göstermemektedir $(\mathrm{p}>0,05)$.

Tablo 6: Öğrencilerin Genel ve Akademik Erteleme Eğilimlerinin Sınıfa Göre Farklılaşmasına Yönelik

Bulgular

\begin{tabular}{|c|c|c|c|c|c|c|c|}
\hline $\begin{array}{l}\text { Ertelem } \\
\text { Eğiliml }\end{array}$ & & Sinıf & $\mathbf{n}$ & $\bar{x}$ & S.S. & $\mathbf{t}$ & $\mathbf{p}$ \\
\hline \multirow{2}{*}{$\begin{array}{l}\text { Genel } \\
\text { Eğilimi }\end{array}$} & \multirow[t]{2}{*}{ Erteleme } & 1. Sinif & 86 & 50,11 & 9,45 & \multirow{2}{*}{$-3,215$} & \multirow{2}{*}{$0,002 *$} \\
\hline & & 2. Sinif & 54 & 56,54 & 12,53 & & \\
\hline \multirow{2}{*}{\multicolumn{2}{|c|}{$\begin{array}{l}\text { Akademik } \\
\text { Erteleme Eğilimi }\end{array}$}} & 1. Sinif & 86 & 56,34 & 9,65 & \multirow{2}{*}{$-2,120$} & \multirow{2}{*}{$0,037 *$} \\
\hline & & 2. Sinıf & 54 & 60,74 & 13,21 & & \\
\hline
\end{tabular}

Araştırmna sonuçlarına göre öğrencilerin genel ve akademik erteleme eğilim düzeyleri sınıfa göre anlamlı bir farklılık göstermektedir $(\mathrm{p}<0,05)$. Ortalamalara göre, 2. sınıf öğrencileri 1. sınıf öğrencilerine oranla göre daha yüksek bir ortalamaya sahiptir. Öyleyse 2. sınıf öğrencilerinin genel ve akademik erteleme eğilimi düzeylerinin 1. sınıf öğrencilere göre daha yüksek olduğunu söylemek mümkündür.

Tablo 7: Öğrencilerin Genel ve Akademik Erteleme Eğilimlerinin Bölüme Göre Farklılaşmasına Yönelik

Bulgular

\begin{tabular}{|c|c|c|c|c|c|c|}
\hline $\begin{array}{l}\text { Erteleme } \\
\text { Eğilimleri }\end{array}$ & Bölüm & $\mathbf{n}$ & $\bar{x}$ & S.S. & $\mathbf{t}$ & $\mathbf{p}$ \\
\hline \multirow{2}{*}{$\begin{array}{l}\text { Genel } \\
\text { Eğilimi }\end{array}$} & Büro Yönetimi ve Yönetici Asistanlığı & 80 & 49,86 & 9,70 & \multirow{2}{*}{$-3,406$} & \multirow{2}{*}{$\mathbf{0 , 0 0 1} *$} \\
\hline & Emlak ve Emlak Yönetimi & 60 & 56,28 & 11,94 & & \\
\hline \multirow{2}{*}{$\begin{array}{l}\text { Akademik } \\
\text { Erteleme Eğilimi }\end{array}$} & Büro Yönetimi ve Yönetici Asistanlığı & 80 & 55,38 & 9,65 & \multirow{2}{*}{$-3,168$} & \multirow{2}{*}{$\mathbf{0 , 0 0 2} *$} \\
\hline & Emlak ve Emlak Yönetimi & 60 & 61,58 & 13,21 & & \\
\hline
\end{tabular}

Tablo 7'ye göre öğrencilerin genel ve akademik eğilim düzeyleri bölüme göre anlamlı bir farklılık göstermektedir $(\mathrm{p}<0,05)$. Ortalamalara bakıldığında, Emlak ve Emlak Yönetimi Bölümünde okuyan öğrenciler Büro Yönetimi ve Yönetici Asistanlığı Bölümünde okuyan öğrencilere göre daha yüksek bir ortalamaya sahiptir. Öyleyse Emlak ve Emlak Yönetimi Bölümünde okuyan öğrencilerin 
genel ve akademik erteleme eğilimi düzeylerinin, Büro Yönetimi ve Yönetici Asistanlı̆̆ 1 Bölümünde okuyan öğrencilere oranla daha yüksek olduğunu söylemek mümkündür.

Tablo 8: Öğrencilerin Genel ve Akademik Erteleme Eğilimlerinin Çalışma Durumuna Göre Farklılaşmasına Yönelik Bulgular

\begin{tabular}{lllllll}
\hline $\begin{array}{l}\text { Erteleme } \\
\text { Eğilimleri }\end{array}$ & Çalışma Durumu & n & $\bar{x}$ & s.s. & $\mathbf{t}$ & $\mathbf{p}$ \\
\hline \multirow{2}{*}{$\begin{array}{l}\text { Genel Erteleme } \\
\text { Eğilimi }\end{array}$} & Çalışan & 21 & 56,48 & 9,70 & & \\
& Çalışmayan & 119 & 51,93 & 11,94 & 1,735 & 0,085 \\
\cline { 2 - 7 } & Çalışan & 21 & 62,00 & 12,26 & & \\
Erteleme Eğilimi & Çalışmayan & 119 & 57,34 & 11,05 & 1,754 & 0,082 \\
\hline
\end{tabular}

Tablo 8 incelendiğinde öğrencilerin genel ve akademik eğilim düzeyleri çalışma durumuna göre anlamlı bir farkl1l1k göstermemektedir $(\mathrm{p}>0,05)$.

Öğrencilerin genel ve akademik erteleme eğilimlerinin yaşa ve gelir seviyelerine göre değişip değişmediğini tespit etmek için tek yönlü varyans analizi uygulanmıştır.

Tablo 9: Öğrencilerin Genel ve Akademik Erteleme Eğilimlerinin Yaşa Göre Farklılaşmasına Yönelik

Bulgular

\begin{tabular}{lllllll}
\hline $\begin{array}{l}\text { Erteleme } \\
\text { Eğilimleri }\end{array}$ & Yaş & $\mathbf{n}$ & $\bar{x}$ & s.s. & F & p \\
\hline Genel & $17-25$ & 132 & 52,46 & 11,28 & & \\
Erteleme & $26-35$ & 6 & 54,33 & 9,25 & 0,273 & 0,761 \\
Eğilimi & 36 ve üstü & 2 & 57,50 & 10,61 & & \\
\hline Akademik & $17-25$ & 132 & 58,11 & 11,18 & & \\
Erteleme & $26-35$ & 6 & 59,00 & 16,22 & 0,464 & 0,630 \\
Eğilimi & 36 ve üstü & 2 & 50,50 & 3,54 & & \\
\hline
\end{tabular}

Tablo 9'a göre öğrencilerin genel ve akademik eğilim düzeyleri yaşa göre anlamlı bir değişiklik bulunmamaktadır ( $\mathrm{p}>0,05)$.

Tablo 10: Öğrencilerin Genel ve Akademik Erteleme Eğilimlerinin Gelir Düzeyine Göre Farklılaşmasına Yönelik Bulgular

\begin{tabular}{|c|c|c|c|c|c|c|}
\hline $\begin{array}{l}\text { Erteleme } \\
\text { Eğilimleri }\end{array}$ & Gelir Düzeyi & $\mathbf{n}$ & $\bar{x}$ & S.S. & $\mathbf{F}$ & $\mathbf{p}$ \\
\hline \multirow{5}{*}{$\begin{array}{l}\text { Genel } \\
\text { Erteleme } \\
\text { Eğilimi }\end{array}$} & 500 £ ve daha az & 48 & 53,15 & 9,45 & \multirow{5}{*}{1,640} & \multirow{5}{*}{0,168} \\
\hline & 501-1000 & 55 & 50,75 & 9,67 & & \\
\hline & 1001-1500€ & 16 & 55,94 & 13,72 & & \\
\hline & 1501-2000€ & 7 & 59,86 & 17,88 & & \\
\hline & $2001 €$ ve üstü & 14 & 50,71 & 13,80 & & \\
\hline \multirow{5}{*}{$\begin{array}{l}\text { Akademik } \\
\text { Erteleme } \\
\text { Eğilimi }\end{array}$} & $500 €$ ve daha az & 48 & 58,45 & 8,88 & \multirow{5}{*}{0,994} & \multirow{5}{*}{0,413} \\
\hline & 501-1000 ‡ & 55 & 56,50 & 11,50 & & \\
\hline & 1001-1500€ & 16 & 60,81 & 12,22 & & \\
\hline & 1501-2000€ & 7 & 63,29 & 15,04 & & \\
\hline & 2001€ ve üstü & 14 & 58,07 & 14,84 & & \\
\hline
\end{tabular}

Elde edilen bulgulara göre öğrencilerin genel ve akademik eğilim düzeyleri gelir seviyelerine göre anlamlı bir farkl11ık yoktur ( $>0,05)$. 


\section{Sonuç ve Öneriler}

Araştırmada değerlendirme kapsamına alınan 140 öğrenci bulunmaktadır. 17-25 yaş aralığ 1 katılımcılar tüm grubun \%94.3'ünü oluşturmaktadır. Verilerin üniversite öğrencisinden toplandığı düşünüldüğünde çoğunluğun bu grupta olması beklenilen bir durumdur. Cinsiyete göre öğrencilerin \% 46,4'u kadın, \%53,6'i erkektir. Öğrencilerin \%1,4'ü evli iken \%98,6'sı bekârdır. Sınıflara göre 1. Sınıf öğrencileri tüm grubun \%61,4'sini, 2. Sınıf öğrencileri ise \%38,6'sını oluşturmaktadır. Bölümlere göre incelendiğinde öğrencilerin \%57,1'i Büro Yönetimi ve Yönetici Asistanlığı, \%42,9'u Emlak ve Emlak Yönetimindendir. Tüm grupta çalışan öğrencilerin oranı \%15'tir. Öğrencilerin gelir düzeyleri ise $500 €$ ve daha az olanlar \%34,3, 501-1000 € aras1 \%11,4, 1501-2000 € aras1 \%5,0, $2001 €$ ve üstü \%10,0 şeklindedir.

Araştırma kapsamında gerçekleştirilen analizlere göre öğrencilerin genel ve akademik erteleme puanlarının ortalama puandan yüksek olduğu ve ortalamaların birbirine yakın olduğu anlaşıldığından, öğrencilerin genel ve akademik erteleme eğilime sahip oldukları söylenebilir. Bu sonuç Ellis ve Knaus (1977); Solomon ve Rothblum'un (1984) ve Ferrari ve Scher'in (2000) araştırma sonuçlarıyla örtüşmektedir.

Araştırma kapsamında; öğrencilerin akademik erteleme eğilimleri ile genel erteleme eğilimleri arasında ilişki olup olmadığını, ilişki varsa bu ilişkinin gücünü ve yönünü belirlemek üzere yapılan Pearson Korelasyon Testi verilerine göre öğrencilerin akademik erteleme eğilimleri ile genel erteleme eğilimleri arasında anlamlı bir ilişki vardır $(p<0,01)$. Akademik ve genel erteleme eğilimi arasında yüksek düzeyde ve pozitif bir ilişki bulunmaktadır $(\mathrm{r}=0,74)$. Dolayısıyla, genel erteleme davranışı sergileyen öğrencilerin akademik erteleme davranışı da sergileyeceği veya tam tersi akademik erteleme davranışı sergileyen öğrencinin genel erteleme davranışını da sergileyeceği söylenebilir. Bu sonuç Milgram ve arkadaşlarının (1993) yaptıkları, genel ve akademik erteleme davranışı arasında bir ilişki olmadığ 1 yönündeki çalışmaya ters düşmektedir. Ancak ertelemenin kişilik özelliği -bireyin yaşamın pek çok alanında ertelemeye yatkın olması- ve davranışsal yatkınlık olduğunu öne süren (Milgram\&Tenne, 2000)'nin çalışması ile örtüşmektedir. Aynı zamanda Kagan (2009) ve Şirin'in (2011) genel erteleme davranışı sergileyen kişinin akademik erteleme davranışını da sergileyeceği veya akademik erteleme davranışı sergileyen bir kbireyin genel erteleme davranışını da sergileyeceği sonucuna ulaştıkları çalışmalarla örtüşmektedir.

Alan yazında erkeklerin kadınlara oranla daha yüksek erteleme eğilimi sergilediği yönünde bulgularda mevcuttur (Baltac1, 2017: 71; Balkıs (2007); Balkıs\&Duru (2009); Kandemir (2014); Uzun-Özer (2005); Yeşil\&Şahan (2012) . Bazı araştırmalarda ise kadınların erkeklere oranla ertelemeye daha eğilimli olduğu yönünde sonuçlar elde edilmiştir (Vestervelt, 2000; Pychyl, Coplan\&Reid, 2002).Araştırma sonucunda; öğrencilerin genel ve akademik erteleme eğilimlerinin cinsiyete, medeni duruma, sınıfa, bölüme ve çalışma durumuna göre değişiklik gösterip göstermediğini belirlemek için yapılan bağımsız örneklem t-testi uygulamasına göre öğrencilerin genel ve akademik eğilim seviyelerinin cinsiyete, medeni duruma ve çalışıp çalışmamalarına göre anlamlı bir farklılık göstermediği $(\mathrm{p}>0,05)$ anlaşılmıştır. Çeşitli araştırmalarda elde edilen ve cinsiyetle erteleme eğilimi arasında bir ilişki olmadığını belirleyen (Aydoğan, 2008; Gülebağlan, 2003; Özer\&Altun, 2011; Watson, 2001) çalışma sonuçları bu çalışma sonucu ile benzerlik bulunmaktadır.

Araştırma sonucuna göre; öğrencilerin genel ve akademik eğilim düzeyleri sınıfa göre anlamlı bir farklılık göstermektedir $(\mathrm{p}<0,05)$. Ortalamalara göre 2. sinıf öğrencileri 1. sınıf öğrencilerine göre daha yüksek bir ortalamaya sahiptir. Öyleyse 2. sınıf öğrencilerinin genel ve akademik erteleme eğilimi düzeylerinin 1. sınıf öğrencilere göre daha yüksek olduğu söylenebilir. $\mathrm{Bu}$ sonuç Doğan ve arkadaşlarının yaptı̆̆ (2015) araştırmada elde edilen erteleme davranışı ortalamalarının sınıf düzeyi yükseldikçe arttığı sonucuyla benzerlik göstermektedir. 
Araştırmadan çıkarılan sonuçlara göre öğrencilerin genel ve akademik eğilim düzeyleri bölüme göre de anlamlı bir farklılık göstermektedir $(p<0,05)$. Ortalamalara göre Emlak ve Emlak Yönetimi Bölümü öğrencileri Büro Yönetimi ve Yönetici Asistanlığı Bölümünü öğrencilerine göre daha yüksek bir ortalamaya sahiptir. Bu nedenle Emlak ve Emlak Yönetimi Bölümünde okuyan öğrencilerin genel ve akademik erteleme eğilimi düzeylerinin, Büro Yönetimi ve Yönetici Asistanlığı Bölümünde okuyan öğrencilere göre daha yüksek olduğunu söylemek mümkündür. $\mathrm{Bu}$ sonuç literatürdeki öğrenim görülen bölümlerin farklılığı ve dolayısıyla ödev, uygulama, sınav ya da proje sayılarının farklılığı ile akademik erteleme davranışı gösterilmesi bağlantılı olabilir (Arıkan, 2016) görüşü ile örtüşmektedir.

Literatürde yaş arttıkça erteleme eğiliminin azaldığı yönünde araştırma sonuçlarına rastlanmaktadır (Baltac1, 2017; Balkıs\&Duru (2009); Ferrari, Johnson\&McCown (1995); Gülebağlan (2003); Güner (2008); Yazıcı\&Bekaroğlu (2012), Tufan\&Gök (2009), Çelikkaleli\&Akbay (2013). Öğrencilerin genel ve akademik erteleme eğilimlerinin yaşa ve gelir düzeylerine göre değişiklik gösterip göstermediğini saptamak için bu araştırmada uygulanan tek yönlü varyans analizine göre genel ve akademik erteleme eğilim düzeyleri yaşa ve gelir seviyesine göre anlamlı bir farklılık bulunmamaktadır ( $>0,05)$.

Kagan'ın (2009) akademik erteleme ile bağlantılı olduğunu düşündüğü değişkenlerle ilgili araştırmasında, zaman yönetimi değişkeni akademik ertelemeyi genel ertelemeden sonra yordayan en güçlü etken olarak saptanmıştır. Bireyleri amaçlarına ulaştıracak ve başarılı kılacak etkili bir yönetim süreci için zaman yönetimi yetkinliklerine sahip olmak yani planlama, düzenleme ve kontrol önemli faktörlerdir. Yapılan araştırmalar, erteleme eğilimi yüksek olan kişilerin zamanı etkili kullanamadıkları ve zamanı denetleme, düzenleme ve değerlendirme eğilimlerinin düşük olduğu kişilerde, akademik erteleme eğiliminin fazla olduğu şeklindedir (Balkıs ve ark., 2006; Kağan, 2009).

Sarıkaya-Aydın ve Koçak (2016) yaptıkları araştırma; öğrencilerin zamanı yönetme düzeyleri yükseldikçe, akademik erteleme davranışlarına ilişkin eğilimlerinin azaldığını ve aynı zamanda akademik erteleme eğilimlerinin daha çok eğlence, internet ve başka zaman tüketicilerine karşı koyma düzeyleri ile ilişkili olduğu sonucunu vermiştir. Erdem ve arkadaşlarının yaptığı (2005) çalışmaya göre üniversite öğrencilerinin internet, televizyon, radyo ve boş sohbet benzeri zaman harcattırıcılar, öğrencilerin zamanının önemli bir kısmını kapsamaktadır. Özellikle sosyal medya bağımlılığının toplumun her katmanında gittikçe yaygınlaştığı günümüzde internet kullanımı aşırıllı̆ 1 ve dolayısıyla Facebook, WhatsApp, Instagram gibi sosyal medya uygulamalarına çok zaman ayırmanın kişilerin günlük işleriyle akademik/mesleki sorumluluklarını aksattığı yönünde araştırmalar mevcuttur (Andreassen, 2012; Akdemir, 2013; Kızılkaya-Cumaoğlu\&Diker-Coşkun, 2012; Yeboah\&Ewur, 2014; Gürültü, 2016; Gür vd., 2018). Vivian'1n (2011) araştırmasında elde ettiği sonuca göre kişilerin erteleme davranışlarının temelinde aşırı Facebook kullanımı ve kendilerini denetleyememeleri bulunmaktadır. Ertelemeye neden olan faktörler arasında akıllı telefon bağımlılığı (nomofobi) de bulunmaktadır. Mert ve Akın'ın (2018) araştırmalarına göre; genel erteleme ile bilgiye ulaşamama, bağlantıyı yitirme, iletişime geçememe, huzurlu hissetmeme alt boyutlarının toplam puanları arasında pozitif yönlü anlamlı ilişki bulunmaktadır.

Zamanı etkili kullanma becerilerine sahip olmadıklarından dolayı akademik erteleme davranışı gösteren öğrencilerin bu bağlamda akademik görevlerini etkili zaman yönetimiyle sürdürebilecekleri ve erteleme davranışından uzaklaşabilecekleri düşüncesiyle öğretim kurumlarına; ders programlarına zaman yönetimi dersi koymaları önerilmektedir. Bunun yanı sıra zaman yönetimi konusunda öğretim elemanlarını da kapsayan konferans ya da seminerler de düzenlenmesi ve onların öğrencilere bu yönde koçluk ve mentorluk yapabilme yetkinliğine kavuşturulmaları da önerilmektedir.

Zamanı etkili kullanmayan ve erteleme davranışları olan kişiler, sosyal medyaya dair yaşadıkları çatışma ile birlikte başladıkları işleri sona erdirememe, iş, aile ve sosyal yaşam gereği 
Üniversite Öğrencilerinin Genel Erteleme Davranışları ile Akademik Erteleme Davranışları... 1213

olan bazı ödev ve sorumlulukları boşlama, üretkenliğin azalması gibi sorunlarla da yüz yüze kaldıklarından (Ekşi vd., 2019: 730) üniversiteler sosyal medya bağımlılığı konusunda öğrencilerin farkındalıklarını artıracak etkinlikler düzenlemelidir. Öte yandan genel olarak nomofobi (cep telefonu bağlantısının kesilmesi korkusu- akıllı telefon bağımlılı̆̆ı) ve genel erteleme arasında anlamlı bir ilişki olduğu ortaya çıkmış olduğundan (Mert\&Akın, 2018) dolayısıyla zamanı verimli kullanamamaktan kaynaklanan gündelik iş ve önemli işlerde pekçok sorun ortaya çıkabileceğinden, üniversitelerin öğrencilerin nomofobi farkındalığını artırmaları da önerilmektedir.

Yine öğretim kurumları; öğretim elemanlarının sınıf yönetimi konusunda yeterliklerini geliştirebilecekleri, pedagojik formasyon programları düzenlemeli ve öğretim elemanları öğrencilerini akademik olarak güdülemelerini ve özyeterliklerini artırıcak etkide bulunmalarını sağlamalıdır. Tüm bunlarla beraber öğretim kurumlarında etik, meslek etiği gibi derslerin tüm öğretim programlarında yer alması da önerilmektedir. Çünkü ahlaki değerler, ahlaki kodlar, dürüstlük, saygı, onur, sorumluluk gibi kavramlara farkındalığın artırılması da akademik erteleme davranışını azaltacaktır. Zira Ayyıldız'ın (2016) araştırmasında da genel ertelemeyi ve akademik ertelemeyi etkileyen en önemli bağımsız değişkenin değerler olduğu ortaya çıkmıştır.

Bu çalışmada genel erteleme davranışı ile akademik erteleme davranışı eğilimi nicel olarak incelenmiştir. Daha sonra bu konuda araştırma yapacak araştırmacılara nitel araştırmalarla konuyu derinlemesine incelemeleri önerilebilir.

\section{Kaynakça}

Akça, F. (2012). An investigation into the self-handicapping behaviors of undergraduates in terms of academic procrastination, the locus of control and academic success. Journal of Education and Learning, 1(2), 288-297.

Journal of Education and Learning; Vol. 1, No. 2; 2012

Akdemir, T. N. (2013). İlköğretim öğrencilerinin Facebook tutumları ile akademik erteleme davranışları ve akademik başarıları arasındaki ilişkilerin incelenmesi. Yüksek Lisans Tezi, Marmara Üniversitesi, Fen Bilimleri Enstitüsü, İstanbul.

Akinsola, M.K., Tella, A., \& Tella, A. (2007). Correlates of academic procrastination and mathematics achievement of university undergraduate students. Eurasia Journal of Mathematics, Science \& Technology Education, 3(4), 363-370.

Akkaya, E. (2007). Academic procrastination among faculty of education students: The role of gender, age, academic achievement, perfectionism and depression. Yayınlanmamış Doktora Tezi. METU, Ankara.

Alpar, R. (2010). Spor, sağllk ve eğitim bilimlerinden örneklerle uygulamalt istatistik vegeçerlikgüvenirlik. Ankara: Detay Yayıncılık.

Andreassen, C. S. (2012). Development of a Facebook addiction scale. Psychological Reports, $110(2), 501-517$.

Arıkan, H. E. (2016). Öğretmen adaylarının öğrenilmiş güçlülük düzeyleri ile akademik erteleme eğilimleri arasındaki ilişkinin incelenmesi. Yayımlanmamış Yüksek Lisans Tezi, Cumhuriyet Üniversitesi, Sivas.

Aydoğan, D.( 2008). Akademik erteleme davranışının benlik saygısı, durumluluk kaygl ve öz yeterlilik ile açıklanabilirliği. Yüksek Lisans Tezi, Ankara Üniversitesi, Ankara. 
Aydoğan, D. \&Özbay, Y. (2012). Akademik erteleme davranışının benlik saygısı, durumluluk kayg1, öz-yeterlik açısından açıklanabilirliğinin incelenmesi. Pegem Ĕgitim ve Ögrretim Dergisi, 2 (3), 1-9.

Ayyıldız, F. (2016). Ergenlerin sahip oldukları değerler ile akademik erteleme ve genel erteleme düzeyleri arasındaki yordayıcı ilişkiler. Yüksek Lisans Tezi, Necmettin Erbakan Üniversitesi, Eğitim Bilimleri Enstitüsü, Konya.

Balkıs, M. (2007). Öğretmen adaylarının davranışlarındaki erteleme eğiliminin, karar verme stilleri ile ilişkisi. Pamukkale Üniversitesi Eğitim Fakültesi Dergisi, 1, 67-83.

Balkıs, M.\&Duru, E. (2010). Akademik erteleme eğilimi, akademik başarı ilişkisinde genel ve performans benlik saygısının rolü, Pamukkale Üniversitesi Eğitim Fakültesi Dergisi, 27, 159-170.

Balk1s, M., \& Duru, E. (2009). Prevalance of academic procrastination among pre-service teachers, and its relationship with demograp-hics and individual preferences. Journal of Theory and Practice in Education, 5(1), 18-32.

Balkıs, M., Duru, E., Buluş, M.\&Duru, S. (2006). Üniversite öğrencilerinde akademik erteleme eğiliminin çeşitli değişkenler açısından incelenmesi. Ege Ë̆itim Dergisi, 2(7), 57-73.

Baltac1, A. (2017). Sınıf öğretmenlerinin erteleme davranışı eğilimleri ve kişilik özellikleri arasındaki ilişkiler, OPUS - Uluslararası Toplum Araştırmaları Dergisi, 7(12), 54-81.

Beck, B. L., Koons, S. R., \& Milgram, D. L. (2000). Correlates and consequences of behavioral procrastination: The effects of academic procrastination, self-consciousness, self-esteem and self-handicaping. Journal of Social Behavior and Personality [Special Issue], 15, 3-13.

Beswick, G., Rothblum, E. D., \& Mann, L. (1988). Psychological antecedents of student procrastination. Australian Psychologist, 23 (2), 207- 217.

Bulut, R. (2015). Sosyal bilgiler öğretmen adaylarının akademik erteleme davranışlarının çeşitli değişkenler açısından incelenmesi. Uluslararası Sosyal Araştırmalar Dergisi, 8(39), 595603.

Burka, J. B. \& Yuen, L. M. (1983). Procrastination: Why you do it, what to do about it. New York: Addison-Wessley.

Chun Chu, A. H., \& Choi, J. N. (2005). Rethinking procrastination: Positive effects of "active" procrastination behavior on attitudes and performance. The Journal of Social Psychology, 145(3), 245-264.

Çakıc1, D. Ç. (2003). Lise ve Üniversite Öğrencilerinde Genel Erteleme ve Akademik Erteleme Davranışının İncelenmesi. Yayınlanmamış Yüksek Lisans Tezi. Ankara: Ankara Üniversitesi, Eğitim Bilimleri Enstitüsü.

Çam, Z. (2013). Ergenlerde genel ve akademik erteleme davranışının yordayıcısı olarak beş büyük kişilik özelliği. Ĕ̆itim ve Öğretim Araştırmaları Dergisi, 2(2), 89-96.

Çelik, B.Ç.\&Odacı, H. (2015). Akademik erteleme davranışlarının bazı kişisel ve psikolojik değişkenlere göre açıklanması, Hacettepe Üniversitesi Eğitim Fakültesi Dergisi, 30 (3), 3147.

Çelikkaleli, Ö., \& Akbay, S. E. (2013). Üniversite öğrencilerinin akademik erteleme davranışı, genel yetkinlik inancı ve sorumluluklarının incelenmesi. Ahi Evran Üniversitesi Kırşehir Eğitim Fakültesi Dergisi, 14(2), 237-254. 
Üniversite Öğrencilerinin Genel Erteleme Davranışları ile Akademik Erteleme Davranışları... 1215

Çetin, Ş. (2009). Eğitim fakültesi öğrencilerinin akademik erteleme davranışlarına ilişkin görüşlerinin incelenmesi. Gazi Üniversitesi Endüstriyel Sanatlar Ë̆itim Fakültesi Dergisi, $25,1-7$.

De Raad, B. (2000). The big five personality factors: The psycholexical ap-proach to personality. New York: Hogrefe \& Huber Publishers.

Deniz, M. E., \& Akdoğan, A. (2014). Farklı depresyon anksiyete stres düzeylerine sahip üniversite öğrencilerinin akademik erteleme davranışlarının incelenmesi. PSIDE Psikolojik Danışma ve Ë̆itim Dergisi, 1(1), 28-44.

Deniz, M.E., Traş, Z.\&Aydoğan, D. (2009). Akademik erteleme ve denetim odağının duygusal zekâ açısından incelenmesi, Kuram ve Uygulamada Eğitim Bilimleri, 9 (2), 607-632.

Doğan, T., Kürüm, A.\&Kazak, M. (2014). Kişilik özelliklerinin erteleme davranışını yordayıcıllğı. Başkent University Journal of Education, 1(1), 1-8.

Duru, E., \& Balkıs, M. (2014). Kendinden şüphe duyma, benlik saygısı ve akademik başarı arasındaki ilişkilerde akademik erteleme eğiliminin rolü. Eğitim ve Bilim, 39(173), 274-287.

Dünyaoğulları, Ö. (2011). Üniversite son sını öğrencilerinin kendilerini gerçekleştirme engelleriyle genel erteleme eğilimi ve umutsuzluk düzeyleri arasındaki ilişkinin incelenmesi. Yayımlanmamış Yüksek Lisans Tezi. Dokuz Eylül Üniversitesi Eğitim Bilimleri Enstitüsü, İzmir.

Ekşi, H. \& Dilmaç, B. (2010). Üniversite öğrencilerinin genel erteleme, karar vermeyi erteleme ve akademik erteleme düzeylerinin sürekli kaygı açısından incelenmesi. Uludă̆ Üniversitesi Eğitim Fakültesi Dergisi, 23(2), 433-450.

Ekşi, H., Turgut, T., \& Sevim, E. (2019). The mediating role of general procrastination behaviors in the relationship between self-control and social media addiction in university students. Addicta: The Turkish Journal on Addictions, 6, 715-743.

Ellis, A., \& Knaus, W. J. (1977). Overcoming procrastination. New York: Signet Books.

Erdem, R., Pirinçci, E., \& Dikmetaş, E. (2005). Üniversite öğrencilerinin zaman yönetimi davranışları ve bu davranışların akademik başarı ile ilişkisi. Manas Üniversitesi Sosyal Bilimler Dergisi, 14(7), 167-177.

Ferrari, J. R. (1991). Self-handicapping by procrastinators: Protecting self-esteem, social esteem, or both? Journal of Research in Personality, 25, 245-261.

Ferrari, J. R., \& Beck, B. L. (1998). Affective responses before and after fraudulent excuses by academic procrastinatior. Education, Summer, 118, 529- 538.

Ferrari, J. R., Johnson, J. L. \& McCown, W. G. (1995). Procrastination and task avoidance: Theory, research, and treatment. New York: Plenum Press.

Ferrari, J.R., O'Callaghan, J., \& Newbegin, I. (2005). Prevalence of procrastination in the United States, United Kingdom, and Australia: Arousal and avoidance delays among adults. North American Journal of Psychology, 7, 1-6.

Ferrari, J. R., \& Scher, S. J. (2000). Toward an understanding of academic and nonacademic tasks procrastinated by students: The use of Daily logs. Psychology in the Schools, 37 (4), 359366.

Flett, G. L., Hewitt, P. L., \& Martin, T. R. (1995). Dimensions of perfection-ism and procrastination. In J. R. Ferrari, J. L. Johnson \& W. G. McCown (Eds), Procrastination and task avoidance: Theory, research and treatment. New York: Springer. 
Green, J. C., Krayder, H., \& Mayer, E. (2005). Combining qualitative and quantitative methods in social inquiry. In B. Somekh \& C. Lewin (Eds.), Research methods in the social sciences (pp. 275-282). London: Sage.

Gülebağlan, C.(2003). Öğretmenlerin işleri son ana erteleme eğilimlerinin, mes-leki yeterlilik algıları, mesleki deneyimleri ve branşları bakımından karşılaştırılmasına yönelik bir araştırma. Yayımlanmamış Yüksek Lisans Tezi. Ankara Üniversitesi, Ankara.

Gün, N.(2010). Küçük turuncu şimdi kitabı. İstanbul: Kuraldış1 Yayıncılık.

Gün, F., Turabik, T., \& Atanur-Baskan, G. (2019). Akademik özyeterlik ile akademik erteleme eğilimi ilişkisi: Aday öğretmenler üzerine bir çalışma. Hacettepe Üniversitesi Eğitim Fakültesi Dergisi, 1 (15), 1-14.

Güner, D. (2008). Illköğretim okullarında görev yapan slnuf ve branş Öğretmenlerinin Erteleme Eğilimleri ve Kaygı Düzeyleri, Yayınlanmamış Yüksek Lisans Tezi. Yeditepe Üniversitesi, İstanbul.

Gür, S. H., Bakırcı, Ö., Karakaş, B., Bayoğlu, F.\&Atli, A. (2018). Üniversite öğrencilerinin sosyal medya bağımlılığının akademik erteleme davranışları üzerindeki etkisi. İnönü Üniversitesi Ĕ̈itim Bilimleri Enstitüsü Dergisi, 5(10), 68-77.

Gürültü, E. (2016). Lise öğrencilerinin sosyal medya bağımlılıkları ve akademik erteleme davranışları arasındaki ilişkinin incelenmesi. Yüksek Lisans Tezi, Marmara Üniversitesi Eğitim Bilimleri Enstitüsü, İstanbul.

He, S. (2017). A Multivariate investigation into academic procrastination of university students. Open Journal of Social Sciences, 5(10), 12-24.

Işık, S. (2019). Erken dönem uyumsuz şemalar ile erteleme davranışı arasındaki ilişki: şema terapi modelinde bir inceleme. Yüksek Lisans Tezi, İstanbul Şehir Üniversitesi, Sosyal Bilimler Enstitüsü, İstanbul.

Johnson, J. L., \& Bloom, A. M. (1992). The relationship between procrastination and personality. Unpublished Manuscript, Villanova University.

Kagan, M. (2009). Determining the variables which explain the behavior of academic procrastination in university students. Eğitim Bilimleri Fakültesi Dergisi, 42(2), 113-128.

Kandemir, M. (2010). Akademik erteleme davranışını açıklayıcı bir model. Doktora Tezi, Gazi Üniversitesi, Ankara.

Kandemir, M. (2014). A model explaining academic procrastination behavior. Pegem Eğitim ve Ögretim Dergisi, 4(3), 51-72.

Kandemir, M., İlhan, T., Özpolat, A. R., \& Palanci, M. (2014). Analysis of academic self-efficacy, self-esteem and coping with stress skills predictive power on academic procrastination. Educational Research and Reviews, 9(5), 146-152.

Karataş, H. \& Bademcioğlu, M. (2015). The explanation of the academic procrastination behavior of pre-service teachers with five factor personality traits. Educational Research Association the International Journal, 6(2), 11-25.

Kızılkaya Cumaoğlu, G.\&Diker Coşkun, Y. (2012). Öğretmenlerin akademik erteleme davranışı ile teknoloji kullanım durumları arasındaki ilişki. Electronic Turkish Studies, 7(4), 2237-2247.

Klassen, R.M., Krawchuk, 1. L. \& Rajani, S. (2008). Academic procrastination of undergraduates: Low self-efficacy to self-regulate predicts higher levels of procrastination. Contemporary Educational Psychology, 33(4), 915-931. 
Üniversite Öğrencilerinin Genel Erteleme Davranışları ile Akademik Erteleme Davranışları... 1217

Knaus, W. J. (2000). Procrastination, blame, and change. Journal of Social Behavior and Personality, $15,153-166$.

Kothari, C.R. (2004). Research methodology: methods and techniques. New Delhi: New Age International Publishers.

Mert, A.\&Akın, A. (2018). Üniversite öğrencilerinde akı1lı telefon bağımlılı̆̆ının(nomofobi) genel erteleme üzerindeki etkisi. III. Uluslararası Gençlik Araştırmaları Kongresi, Nahcivan, Azerbaycan.

Milgram, N. (1992). El retraso: Una enfermedad de los tempos modernos [Procrastination: A malady of modern time]. Boletin de Psicologia, 35, 83-102.

Milgram, N. A., Batori, G., \& Mowrer, D. (1993). Correlates of academic procrastination. Journal of School Psychology, 31, 487-500.

Milgram, N., \& Marshevsky, S. (1995). Correlates of academic procrastination: Discomfort, task aversiveness and task capability. Journal of Psychology, 129, 145-155.

Milgram, N., Mey-Tal, G., \& Levinson, Y. (1998). Procrastination, generalized or specific, in colege students and their parents. Personality and Individual Differences, 25, 297-316.

Milgram, N. A., Sroloff, B., \& Rosenbaum, M. (1988). The procrastination of everyday life. Journal of Research in Personality, 22, 197-212

Milgram, N. \& Tenne, R. (2000). Personality correlates of decisional and task avoidant procrastination. European Journal of Personality, 14, 141- 156.

Milgram, N., \& Toubiana, Y. (1999). Academic anxiety, academic procras-tination, and parental involvement in students and their parents. British Journal of Educational Psychology, 69, 345-361.

Nunnally, J. C. (1978). Psychometric theory (2. Bask1). New York: McGraw-Hill.

Odacı H., \& Kaya F., (2019). Mükemmeliyetçilik ve umutsuzluğun akademik erteleme davranışı üzerindeki rolü: Üniversite öğrencileri üzerinde bir araştırma. Yükseköğretim ve Bilim Dergisi, 9(1), 43-51.

Orpen, C. (1998). Th e causes and consequences of academic procrastination: A research note. Westminster Studies in Education, 21, 73-75.

Özdemir, O. S. (2012). Illköğretim okulu yönetici ve öğretmenlerinin genel erteleme davranışları eğilimleri ile düşünme stillerinin analizi. Yüksek lisans tezi, Necmettin Erbakan Üniversitesi, Eğitim Bilimleri Enstitüsü, Konya.

Özer, K. (2002). Kaygl: Sinanma duygusuyla baş edebilme. İstanbul: Sistem Yayıncılık.

Özer, A., \& Altun, E. (2011). Üniversite öğrencilerinin akademik erteleme nedenleri. Mehmet Akif Ersoy Üniversitesi Eğitim Fakültesi Dergisi, 1(21), 45-72.

Patrzek, J., Sattler, S., van Veen, F., Grunschel, C., \& Fries, S. (2015). Investigating the effect of academic procrastination on the frequency and variety of academic misconduct: A panel study. Studies in Higher Education, 40(6), 1014-1029.

Rothblum, E. D., Solomon, L. J., \& Murakami, J. (1986). Affective, cognitive, and behavioral differences between high and low procrastinatiors. Journal of Counseling Psychology, 33, 387-394.

Saddler, C. D., \& Sacks, L. (1993). Multidimensional perfectionism and academic procrastination: Relationship with depression in university students. Psychological Reports, 73, 863-871. 
Sarıkaya-Aydın, K.\&Koçak, S. (2016). Üniversite öğrencilerinin zaman yönetimi becerileri ile akademik erteleme düzeylerinin incelenmesi. Uşak Üniversitesi Eğitim Araştırmaları Dergisi, 2 (3), 17-38.

Saruhan, Ş. C.\&Özdemirci, A. (2011). Bilim, felsefe ve metodoloji (2. Bask1). İstanbul: Beta Yayınevi.

Schouwenburg, H. C., \& Lay, C. H. (1995). Trait procrastination and the big-five factors of personality. Personality and Individual Differences, 18(4), 481-490.

Schouwenburg, H.C., Lay, C., Pychyl, T.A.\&Ferrari, J.R. (2004). Counseling the procrastinator in academic settings. Washington, DC: American Psychological Association.

Sekaran, U. (2003). Research methods for business: A skill building approach (4. Bask1). New York: John Wiley \& Sons, Inc.

Sirois, F. M. (2007). "I'll look after my health, later": A replication and extension of the procrastination-health model with community-dwelling adults. Personality and Individual Differences, 43, 15-26.

Sirois, F. M. \& Tosti, N. (2012). Lost in the moment? An investigation of procrastination, mindfulness, and well-being. Journal of Rational-Emotive \& Cognitive-Behavior Therapy,30, 237-248.

Sirois, F. M., Melia-Gordon, M. L., \& Pychyl, T. A. (2003). I'll look after my health, later: An investigation of procrastination and health. Personality and Individual Differences, 35(5), $1167-1184$.

Solomon, L., \& Rothblum, E. (1984). Academic procrastination: Frequency and cognitive behavioral correlates. Journal of Counseling Psychology, 31, 503-509.

Şirin, E. F. (2011). Academic procrastination among undergraduates attending school of physical education and sports: Role of general procrastination, academic motivation and academic self-efficacy. Educational Research and Reviews, 6(5), 447-455.

Tabachnick, B. G.\&Fidell, L. S. (2007). Using multivariate statistics (5. Bask1). Boston: Allyn and Bacon.

Tekbıyık, A. (2015). İlişkisel araştırma yöntemi. M. Metin (Editör), Kuramdan uygulamaya eğitimde bilimsel araştırma yöntemleri içinde (2. Bask1) (s. 101-114). Ankara: Pegem Akademi.

Tice, D. M. \& Baumeister, R. F. (1997). Longitudinal study of procrastina-tion, performance, stress, and health: The costs and benefits of dawdling. Psychological Science, 8, 454-458.

Topal, N. (2015). Akademisyenlerde erteleme ile kişilik özellikleri ve mükemmeliyetçilik arasındaki ilişkiler. Yüksek Lisans Tezi, Karadeniz Teknik Üniversitesi, Eğitim Bilimleri Enstitüsü, Trabzon.

Tufan, E., \& Gök, M. (2009). Müzik öğretmeni adaylarının genel ve akademik erteleme eğilimlerinin çeşitli değiş̧kenler açısından incelenmesi, 8. Ulusal Müzik Eğitimi Sempozyumu, Samsun. 23-25.

Ural, A. \&Kılıç, İ. (2013). Bilimsel araştırma süreci ve SPSS ile veri analizi (4. Baskı). Ankara: Detay Yayıncılik.

Uzun, B.\&Demir, A. (2015). Erteleme: Türleri, bileșenleri, demografik etkenler ve kültürel farkl11ıklar. Ege Eğitim Dergisi, 16(1), 106-121. 
Üniversite Öğrencilerinin Genel Erteleme Davranışları ile Akademik Erteleme Davranışları... 1219

Uzun-Özer, B. (2005). Academic procrastination: Prevalence, sef-reported rea-sons, gender difference and it's relation with academic achievement. Yayınlanmamış Yüksek Lisans Tezi, Ortadoğu Teknik Üniversitesi, Ankara.

Vestervelt, C. M. (2000). An examination of the content and construct validity of four measures of procrastination. Yayınlanmamış Yüksek Lisans Tezi, Carleton Üniversitesi, Kanada.

Vivian, R. (2011). University students informal learning practices using Facebook: Help or hindrance? New York, NY: Springer Berlin Heidelberg.

Wang, Z. \& Englander, F. (2010). A cross-disciplinary perspective on explaining student performance in introductory statistics. What is the relative impact of procrastination? College Student Journal, 44, 458-471.

Watson, D. C. (2001). Procrastination and the five-factor model: A facet level analyses. Personality and Individual Differences, 30, 149-158.

Yazıcı, H., \& Bekaroğlu, B. (2012). Örgün eğitim kurumlarında görev yapan müdürlerin erteleme davranışlarının okul yönetimine etkisi. Bayburt Eğitim Fakültesi Dergisi, 7(2), 169-180.

Yeboah, J., \& Ewur, G. D. (2014). The Impact of Whatsapp messenger usage on students performance in tertiary institutions in Ghana. Journal of Education and Practice, 5(6), $157-$ 164.

Yeşil, R., \& Şahan, E. (2012). Öğretmen adaylarının akademik işlerini erteleme nedenleri. Abant İzet Baysal Üniversitesi Ĕgitim Fakültesi Dergisi. 12 (2), 219-236.

Yıldırım, N. N. (2014). Üniversite ögrencilerinde erteleme davranışının mükemmeliyetçilik ve

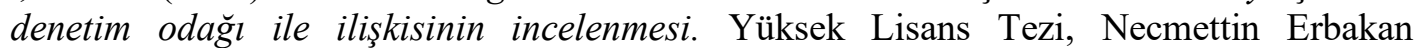
Üniversitesi, Eğitim Bilimleri Enstitüsü, Konya.

Y1ldı, S., \& Y1ldız, K. (2016). The relationship between academic procrastination and hopelessness perceptions of primary school teaching department students. International Online Journal of Educational Sciences, 8(3), 234-251. 